\title{
Processos e práticas de educação e formação. Para uma análise da realidade portuguesa em contextos de globalização*
}

\author{
José Augusto Pacheco \\ Universidade do Minho, Portugal
}

\begin{abstract}
Resumo
Numa análise crítica dos recentes processos e práticas de educação e formação, definidos pela agenda da União Europeia e de outros organismos, colocamos no centro do debate a relação entre globalização, conhecimento e currículo, de modo a salientar as mudanças ao nível da educação formal, não formal e informal para o estudo do currículo. Sublinhamos que as políticas de educação e formação são processos complexos de decisão, dependentes de territorialidades diferentes e entrelaçadas, com o objectivo de responder afirmativamente a uma mudança económico-social mais ampla. É nesta lógica estruturada de decisão política que situamos o estudo do currículo no contexto de políticas globalizadas, por um lado, e das políticas nacionais, por outro, reconhecendo que ambas estão edificadas em torno do conhecimento.
\end{abstract}

Palavras-chave

Globalização; Educação; Formação; Currículo

\section{Introdução}

Os processos e práticas de educação e formação portugueses estão cada vez mais integrados em agendas globalmente estruturadas, cujo eixo de influência se situa no quadro comum das políticas da União Europeia e de outros organismos, com destaque para a OCDE. Tanto no ensino superior, como nos ensinos secundário e básico, as orientações educativas 
subordinam-se a um processo de decisão supranacional, deixando-se para os governos de cada Estado-membro decisões que em nada alteram a existência de uma estrutura partilhada em termos de alguns critérios amplamente consensualizados.

Numa análise crítica dos recentes processos e práticas de educação e formação, em especial desta primeira década do século XXI, colocamos no centro do debate a relação entre globalização, conhecimento e currículo, de modo a salientar as mudanças ao nível da educação formal, não formal e informal para o estudo do currículo. Sublinhamos que as políticas de formação e educação são processos complexos de decisão, dependentes de territorialidades diferentes e entrelaçadas, com o objectivo de responder afirmativamente a uma mudança económico-social mais ampla. É nesta lógica estruturada de decisão política que situamos o estudo do currículo no contexto de políticas globalizadas, por um lado, e das políticas nacionais, por outro, reconhecendo que ambas estão edificadas em torno do conhecimento, perspectivado como alavanca do desenvolvimento económico, aliás na esteira da teoria do capital humano, berço conceptual de um dos pressupostos do neoliberalismo educacional (Pacheco, 2001).

$\mathrm{Na}$ busca de esclarecimento sobre os processos e práticas de educação e formação centramo-nos no Processo de Bolonha, para o ensino superior, e nas alterações curriculares, para os ensinos básico e secundário, incluindo também o Programa Novas Oportunidades, concluindo-se que as mudanças no âmbito da educação e formação conduzem não só à uniformização curricular, como também à regulação de resultados, em estreita relação com a ressignificação do currículo.

\section{Processos de educação e formação em contexto de políticas globalizadas}

Na análise da relação entre globalização e educação, Dale (2004: 425) salienta a força do efeito extranacional, reconhecendo que "o desenvolvimento dos sistemas educativos nacionais e as categorias curriculares se explicam através de modelos universais de educação, de Estado e de sociedade, mais do que através de factores nacionais distintivos". Por isso, a educação é analisada quer na base da "cultura educacional 
mundial comum" e da "cultura universal de educação" (idem), quer no quadro de uma "instituição mundial" (Azevedo, 2007), quer, ainda, no contexto da "teoria do sistema mundial" (Adick, 1993).

Subordinada a lógicas específicas, em que sobressaem os discursos sobre a qualidade dos sistemas de educação e formação e sobre a gestão do conhecimento como um recurso económico, a globalização percorre os caminhos do neoliberalismo, pois são dois fenómenos estreitamente ligados (Charlot, 2007), e reforça os mecanismos de convergência da decisão política em áreas fundamentais, tais como a educação e a formação.

De acordo com Ritzer (2007: 4), que parte da constatação de que as nossas vidas quotidianas estão cada vez mais globalizadas, nas últimas décadas, tem emergido um corpo de conhecimento académico distinto, conhecido por teoria da globalização, e que define como "a difusão de um sistema mundial de práticas, a expansão de relações intercontinentais, a organização da vida social a uma escala global e o incremento de uma consciência global partilhada".

Porque é "um conjunto de processos" (Giddens, 2007: 13), e porque os seus pressupostos são económicos, políticos e culturais, a análise que Ritzer (2007) faz da globalização inclui a abordagem pluridisciplinar, na pressuposição de que existem, pelo menos, três teorias.

As teorias políticas da globalização, especialmente na forma do pensamento neoliberal, abraçam duas realidades distintas: a defesa do princípio do livre mercado, sem que existam barreiras estabelecidas pelos Estados-nação e por outras entidades políticas; o reconhecimento do primado da perspectiva realista de que a globalização é o resultado das relações de poder entre diversos Estados-nação. Com base na teoria do sistema mundial, as teorias económicas da globalização problematizam não só a relação desigual entre nações centrais e nações periféricas, ou semi-periféricas, como também a emergência do capitalismo informacional. $\mathrm{Na}$ abordagem dos aspectos culturais da globalização, o autor refere três tendências principais dissemelhança cultural; convergência cultural; hibridismo cultural — para concluir que se trata de um processo múltiplo que ocorre tanto ao nível da superfície, quanto ao nível das estruturas profundas das culturas, ainda que, na prática, a homogeneização se sobreponha à heterogeneização com as suas formas específicas de domínio e convergência, e que se traduzem pela 
"globalização do nada", ou seja, pelas "nulidades" dos "não-lugares", "nãocoisas", "não-pessoas" e "não-serviços".

Mas que efeitos têm tais teorias da globalização sobre os processos de educação e formação?

Numa primeira análise, os efeitos económicos são os mais visíveis, por exemplo, pela introdução de padrões de eficiência e qualidade, pela privatização de serviços e pela economização do conhecimento, aceitando-se que, a nível político, são cada vez mais convergentes os modos de regulação das políticas educacionais e que, a nível cultural, são transnacionalizados padrões comuns que resultam do reconhecimento de princípios quanto a modos de ser e de viver.

Face à existência de modelos transnacionais de educação e formação, e face a processos amplos de convergência, a globalização tem um rosto que se identifica com a uniformização e com a ideia que tudo se torna igual, independentemente dos contextos nacionais, já que, nesse processo, as "nações deixam de ser unidades autónomas, independentes, interagindo entre si, para serem territórios atravessados pelo fluxo da modernidademundo" (Ortiz, 2006a: 25).

Do fluxo transnacional, que regula processos e práticas na forma de pensar e agir, resulta a construção do nacional em subordinação não à máxima da década de 1980 - pensar global, actuar localmente, mas à expressão dos dias de hoje - pensar global, agir globalmente, de modo a criar-se a ideia de que um Estado não sobrevive fora do circuito de produção da nova ordem económica. Ainda que neste processo se verifique a recuperação do sentido identitário promovido pelo espaço local ${ }^{1}$, outrora destruído pela uniformização operada pelo movimento em torno do Estado e da Nação, enquanto processos de aglutinação, respectivamente, territorial e cultural, a fragilização do nacional decorre da existência de macro-decisões ligadas a todos os aspectos da vida dos Estados, desde as políticas económicas e financeiras até às políticas sociais, culturais e educacionais.

No campo educacional, cada Estado-membro segue uma "agenda globalmente estruturada" (Dale, 2004; Teodoro, 2003), sendo previsível que os seus efeitos nas políticas nacionais tendam para a homogeneidade e uniformização em detrimento da diversidade e identidade. Embora o seu 
propósito principal se centre na uniformização, a globalização liga-se, de igual modo, à individualização pessoal, ao reforço do espaço local e a noções como identidade, diversidade e projecto (Moreira, 2006), sobretudo quando se coloca do lado das escolas e dos professores a responsabilidade pelos resultados escolares.

Porém, tal reconhecimento do papel dos actores nos processos de educação e formação pode ser entendido não como a assunção de responsabilidades distintas pela concepção de projectos, mas pela aceitação de modelos tecnocráticos de decisão, em cujas linhas de acção se encontram orientações muito específicas. Por mais orientações de programas políticos que existam, sempre radicadas na utopia da mudança e na promessa quantas das vezes incumprível, as decisões em áreas-chave, por exemplo, Educação, Saúde, Justiça, Economia e Segurança, dependem, fundamentalmente, de grupos de trabalho, constituídos por especialistas e técnicos. Esta ideias tornam-se politicamente correctas, originando a despolitização técnica dos processos e práticas das reformas. O que se propõe como reforma educativa é, na maioria das situações, uma plétora de medidas técnicas, sempre muito centralizadas em pareceres técnicos de grupos de trabalho, politicamente orientados e controlados, sem o sentido real da mudança escolar.

No que diz respeito à educação e formação, a mudança transnacional circunscreve-se a modelos institucionais padronizados, enquadrados pelas ideologias da sociedade da informação e do conhecimento e das novas competências (Azevedo, 2000). Consequentemente, o modelo cultural prevalecente recorre a "ideologias globais e a modelos transnacionais gerais de educação, no seio das quais são veiculadas correntes e perspectivas de reforma que atravessam o mundo inteiro e que afectam, desde logo, os países mais desenvolvidos" (Azevedo, 2007: 57).

Ao valorizar a educação e formação como traves-mestras da mudança, a globalização reforça os fundamentos da teoria do capital humano, em que se acentua a visão da educação como processo de formação social, orientada para mercados competitivos, clamando que as organizações educativas devem responder a desafios imediatos do mundo económico. Deste modo, diversos organismos transnacionais perspectivam o conhecimento como um recurso económico e, ao mesmo tempo, exigem novos critérios para a qualificação dos cidadãos, regulados por lógicas de 
mercado e definidos na base de uma concepção instrumental da formação, que a fraseologia relativa à pedagogia por competências recupera como indicador principal na sua organização curricular.

Ao funcionar como mecanismo de uniformização, a globalização tece fortes laços, tanto entre conhecimento e economia, como entre educação e formação, pela defesa do princípio de que há um benefício económico se a mão-de-obra for bem instruída e treinada nos sistemas educacionais.

O conhecimento e a informação são duas variáveis da economia que suplantam o trabalho e o capital como valor acrescentado (Kóvacs, 2002), constituindo duas faces de uma mesma sociedade. Por isso, a sociedade da informação e conhecimento não é mais do que uma das condições da globalização, conquanto que a aglutinação dos espaços de decisão contribui para a imposição de uma nova ordem mundial, geradora de políticas comuns, com destaque para os terrenos transnacionais e supranacionais. Por exemplo, a retórica da Aprendizagem ao longo da vida é uma palavra-chave dos documentos da $\mathrm{OCDE}^{2}$ e a Economia de conhecimento é a meta (que não se cumprirá, decerto) que a União Europeia traçou no seu horizonte político de curto prazo (2010).

Sendo mais visíveis os efeitos económicos da globalização, os seus efeitos políticos e culturais ao nível dos processos e práticas de educação e formação não dependem de programas complexos, ou de guiões muito funcionais, mas são observáveis pela inclusão, nas orientações de diversos organismos, de conceitos-chave, tais como "qualidade", "prestação de contas", "aprendizagem ao longo da vida", "economia do conhecimento", "competência", "eficiência". A mudança conceitual, geralmente promovida pela deslocação de avultadas quantias financeiras para a pesquisa e fomento das boas práticas, torna-se no motor da globalização, conferindo-lhe pragmatismo na busca da qualidade e eficiência.

Para o caso da União Europeia, segundo Giddens (2007: 219), está "acordado que a educação geral e o ensino superior em particular não caem no âmbito da política europeia comum. O papel da comunidade está limitado a encorajar a cooperação entre os estados-membros". Tal cooperação passa pela adopção do método aberto de coordenação ${ }^{3}$, caracterizado não só pela concepção e implementação de medidas comunitárias, como também pela divulgação de modelos baseados em boas práticas. Daí que Scott e Kelleher 
(1996), (citados por Azevedo, 2007: 37), refiram que "os sistemas nacionais europeus de educação estão a percorrer, com soluções diversas, caminhos de resposta a um conjunto comum de pressões e problemas".

Detendo-nos na noção de globalização, e analisando-se o suporte doutrinal do neoliberalismo no redesenho das políticas educacionais (Pacheco, 2001), constatar-se-á que o conhecimento, considerado cada vez mais como investimento, é a principal força económica de produção, ainda que se confirme a hipótese de trabalho formulada por Lyotard (2006 [1979]: 3): a de que "o saber muda de estatuto ao mesmo tempo que as sociedades entram na idade dita pós-industrial e as culturas na idade dita pós-moderna".

Sem entrar na discussão filosófica sobre que estatuto é este, importa referir o modo como um determinado modelo de organização do conhecimento foi sendo delineado ao longo do século XX. Idealizada como um espaço nacional, a escola foi tecendo ao nível das suas práticas, que não se tornam tão dissemelhantes quer pela natureza do conhecimento que é ensinado/aprendido quer pela relação pedagógica instituída e pelos materiais curriculares utilizados, um modelo de gestão científica, ancorado nos princípios da eficiência global (tylorismo) e nos pressupostos de uma teoria curricular de natureza instrucional (racionalidade tyleriana) (Pacheco, 2003).

Tal modelo tem por base a disciplinaridade do conhecimento e a abordagem sistémica. É através das disciplinas, com as disciplinas e pelas disciplinas (sempre presentes na escola, mesmo quando existe um modelo integrado, caso da organização curricular dos primeiros anos de escolaridade) que o conhecimento escolar é organizado em planos curriculares, balizas do conhecimento oficial e do currículo nacional, e estruturado em programações (de escola, de ciclo, de ano) e planificações (de classe ou turma). Por mais que se recriem modelos transdisciplinares e/ou interdisciplinares e se inscrevam no mundo escolar áreas de formação pessoal e social, a escola mantém a estrutura básica da disciplina, isto é, um conhecimento compartimentado, fragmentado e reduzido a fronteiras muito fechadas que em nada favorecem o diálogo interdisciplinar, quanto mais a possibilidade de elaborar projectos curriculares integrados.

Ao ser definida como o que "está entre as disciplinas, através das disciplinas e além de toda a disciplina" (Japiassu, 2006: 16), a interdisciplinaridade equivaleria à abordagem curricular que melhor 
responderia ao desafio da globalização para que o conhecimento perca a face singular e represente o esforço intelectual de compreender os contextos e processos de acção humana.

Se a base da escola tradicional é o cognitivismo, a nova escola da globalização e da sociedade do conhecimento está fundamentada na tecnologia da informação, pois "a produção de conhecimento ocorre cada vez mais no âmbito de redes, que podem ser muito remotas, em vez de serem empresas hierárquicas, as quais tendem a nivelar-se em termos dos seus sistemas de autoridade" (Giddens, 2007: 215). No entanto, é de questionar até que ponto a escola deixa de ser o veículo central do conhecimento em sociedades em que a desigualdade se faz a partir de critérios de infoexclusão. Também é de questionar se a escola passará de uma matriz disciplinar para uma matriz interdisciplinar.

Nos mecanismos de regulação escolar, e contrariamente ao que seria de supor, a globalização favorece, por um lado, a balcanização do conhecimento escolar, cavando ainda mais a distância entre o peso curricular atribuído a certas disciplinas (caso da Matemática, Ciências e Inglês) e, por outro, a promoção de saberes escolares estruturantes, traduzidos em competências, que podem limitar a questão do acesso à economia do conhecimento, ligadas às Tecnologias de Informação e Comunicação.

Tanto na década de 1960, em que a escola é chamada a responder à crise militar norte-americana, depois do lançamento do Sptunik, em 1957, como na década de 1980, com o registo de mais uma chamada da escola para ultrapassar a crise económica, desencadeada pela emergência dos países asiáticos, o conhecimento é repensado não na sua base disciplinar, mas no modo como deve ser didacticamente organizado, isto é, pela pedagogia de objectivos e pela pedagogia de competências, sempre dentro do modelo de reengenharia social (Pinar, 2007). Predomina, neste modelo, uma noção objectiva de conhecimento, definido e orientado para o mundo concreto do mercado, pois a escola deve ser o engenho social da fabricação cognitiva de saberes relacionados com contextos específicos da economia.

Neste sentido, "a globalização diz respeito essencialmente ao processo de evolução e organização do sistema económico capitalista no plano mundial" (Dalarosa, 2003: 201), cujo raio de acção política e cultural entronca na pós-modernidade, principalmente naquilo que o individualismo 
pode fazer para a promoção de uma lógica de mercado. A noção de mercado é, decerto, a pedra angular da tendência neoliberal, que se identifica com os princípios da privatização, da globalização e da livre escolha, e que servem de argumento para a eficiência, a qualidade e a equidade. Numa perspectiva liberal clássica, o mercado, resultando do progresso humano, é um artefacto cultural construído nas práticas sociais, aparecendo historicamente antes do Estado, com a função de servir os interesses das pessoas, e constituindo-se, segundo as ideias de Adam Smith, na mão invisível.

Promovendo a subjectivação do sujeito, por vezes sem laços de historicidade, a pós-modernidade "expressa uma cultura de globalização e da sua ideologia neoliberal" (Sanfelice, 2003: 7), fortalecendo a relação intrínseca entre mercado e individualismo em conformidade com os valores da livre escolha, eficiência e qualidade ${ }^{4}$.

Em tempos actuais, com o predomínio de uma discursividade relativa à descentralização das políticas curriculares, o que é comum a todos os sistemas educativos, independentemente das ideologias que os caracterizam e dos processos de mudança que os norteiam, verifica-se que a globalização contribui para a macro-regulação de uma vontade supranacional, no caso da União Europeia, negociada ao nível das políticas económicas e sociais e ao nível dos processos e práticas de educação e formação, tendo como denominador comum a convergência através de uma noção mais ampla de regionalização. De acordo com Hallak (2001), esta regionalização traduz-se na proposição de standards e normas, com a diminuição do papel do Estado, num processo de supra-assunção, como refere Habermas (2002: 143): o lugar do Estado é ocupado pela empresa transnacional, tendo como horizonte a "sociedade global descentrada, que se decompõe em uma quantidade desordenada de sistemas funcionais que se reproduzem e se orientam a si mesmos".

Por mais descentrado que possa ser, o processo de globalização efectiva-se pela padronização de práticas, requerendo "a existência de instituições sociais capazes de produzir, reproduzir e transformar a ordem das sociedades" (Ortiz, 2006a: 74), ao mesmo tempo que se fala de descentralização e de lógicas de individualização. Por isso, as noções de transnacional e supranacional são categorias que invocam e traduzem hierarquia e estandardização, por um lado, e diversificação, por outro, na 
conjugação de padrões pré-definidos com opções dos indivíduos. Um dos exemplos é o que se passa com a comercialização de carros, em que o comprador, depois de escolher o modelo, pode individualizá-lo, mediante uma vasta lista de opções.

A escola é uma dessas instituições que impõem a ordem, a autoridade e a coesão nacional através da organização do conhecimento, não implicando, necessariamente, a existência de um único padrão que seja imposto a todas as escolas. Se a existência de um "mundo sem fronteiras", no dizer de Ortiz (2006b: 48), "está presente num conjunto de escritos sobre marketing e faz parte do léxico empresarial transnacional", é porque é um dos pressupostos da globalização dos processos económicos e tecnológicos, com vista à convergência dos sistemas de educação e formação. Em consequência, a globalização acentua a padronização dos sistemas educativos, quer no que se prende com o reforço do conhecimento escolar, ainda que traduzido em competências e organizado em formatos modulares, quer no controlo da qualidade dos resultados escolares, delimitados por uma cultura de avaliação.

Tal processo de convergência produz três efeitos nos processos e práticas de educação e formação: o primeiro, a retomada de uma visão tecnicista (Candau \& Koff, 2006), apoiada em modelos de racionalidades técnicas (Pacheco, 2003), na metáfora da produção e no modelo de reengenharia social (Pinar, 2007), com um forte impacto quer na organização da escola e do currículo, ao nível da sala de aula e orientada para a discussão dos resultados escolares, quer no fomento de uma concepção instrumental da formação; o segundo, a valorização dos processos de educação não formal e informal, outorgando-se às modalidades de formação de jovens e adultos 0 mesmo estatuto que é reconhecido às organizações escolares; por último, o predomínio de uma perspectiva normativa na concepção e implementação das políticas, sendo que a política curricular é descentralizada ao nível dos discursos, mas recentralizada ao nível das práticas escolares, originando o processo de recontextualização (Pacheco, 2003; 2005a). Parafraseando-se Stromquist (2006: 371), o Estado é esplêndido no discurso escolar sobre as políticas e pobre nas teorias de acção; débil nos esforços para a implementação e tacanho na transferência de recursos. Por mais descentralização que exista nos discursos da Administração, admitir-se-á que 
o Estado central não abdica de todo o seu poder na organização do sistema educativo: se as suas competências se limitam à regulação e ao controlo, o conjunto das tarefas de gestão são delegadas nos actores locais, sobretudo às escolas, que passam a beneficiar de um amplo estatuto de autonomia (Mons, 2004: 46)

A consideração destes três efeitos leva-nos a argumentar que a globalização reforça uma identidade legitimadora e contribui para a uniformização dos processos de educação e formação, conferindo centralidade ao currículo.

Temos vindo a escrever diversos textos ${ }^{5}$, nos quais tentamos problematizar esta questão, sobretudo a partir da noção de identidade, proposta por Castells (2000), e das práticas de uniformização das escolas, tornando-as cada vez mais iguais em contextos de afirmação de projectos locais.

A globalização reforça, por isso, o lado mais uniformizante da escola, sendo de admitir que esta contém, na sua estrutura de funcionamento, princípios de homogeneização ${ }^{6}$, conferidos pelas formas de organizar 0 conhecimento e "pelo modo uniforme e estável das modalidades organizacionais do trabalho escolar" (Canário, 2005: 77), verificando-se que "tende a instituir-se como algo que não é concebível mudar. As diferenças ou nuances institucionais, entre diferentes níveis de ensino, diferentes períodos ou diferentes regiões, não permitem ocultar a universalidade de uma solução organizacional, claramente aparentada com o modo taylorista de organizar a produção industrial" (idem, ibidem). Para Sampaio (1998: 248), e fazendo parte do mundo das organizações de tipo burocrático, devido ao seu modo predominante de regulação e exercício de poder, as escolas têm regras e poder instituídos, onde "o currículo é normatizado por regras e documentos de responsabilidade dos órgãos centrais e dos órgãos regionais, que controlam sua operacionalização e realização nas escolas".

Mais do que outras organizações, as escolas estão estruturadas para responder aos desafios colocados pela globalização, pois

os sistemas escolares têm relevância mundial por três motivos: porque são uma componente do sistema mundial moderno e um subsistema de qualquer país em modernização; porque as suas principais características e funções sociais são relativamente inespecíficas do ponto de vista cultural e são uniformes em todo o mundo; e porque este modelo de escola moderna, novo, moderno e universalmente aplicável, é e será de longa duração (Azevedo, 2000: 145). 
Se a globalização funciona, hoje em dia, no seio das práticas escolares e curriculares, pela discussão do conhecimento, nas décadas de 1980 e 1990 integrava abordagens na base da consciencialização crítica dos alunos para temáticas transnacionais, por exemplo, da formação pessoal e social, do paradigma do desenvolvimento, dos estilos de vida (Gough, 2003). De um alerta inicial, a globalização passa para um conjunto de práticas que reforçam o lado mais uniformizante da escola, sendo de admitir que a escola contém, desde a sua génese e na estrutura de funcionamento, princípios de homogeneização.

Deste modo, a globalização torna-se numa identidade legitimadora (Castells, 2000) de espaços geográficos cada vez mais transnacionais e supranacionais, que reforçam o papel de transmissão de conhecimentos, com base em critérios bem definidos, que a escola tem cumprido. Ainda que as mudanças nas práticas escolares não sejam significativas, pois também é possível argumentar que existe nas escolas uma estrutura invariante ligada ao pensamento e à acção dos professores (Pacheco, 1995), os processos e práticas de educação e formação inerentes à globalização reconceptualizam o currículo do seguinte modo (Martinand, 2001): valorização da orientação escolar e profissional, não nas suas componentes psicológicas, mas na contribuição para a construção de representações muito objectivas dos conteúdos e dos contextos técnicos de trabalho; abordagem do mundo tecnicista; apropriação das técnicas de informação e de comunicação; promoção de uma pedagogia de acção.

De igual modo, a globalização favorece a emergência de identidades ligadas a contextos de ensino mais marcados pelas questões técnicas (gestão da sala de aula, conhecimento da disciplina, resultados dos testes dos alunos) do que pelas questões de natureza pessoal, profissional, social e emocional. Todavia, a globalização, e por aquilo que pode significar o termo mundialização, cujos significados são diferenciados por Ortiz (2006b7), não equivale a uma total uniformização, sobretudo no que diz respeito à relação pedagógica e à contextualização de espaços locais.

Os contextos de ensino são essencialmente produtores de identidades técnicas, já que os professores são mais avaliados e responsabilizados pelo lado dos resultados dos alunos do que pelo seu lado mais pessoal e de gestão dos processos de aprendizagem. 
Quando inscrita numa agenda de performatividade e de estandardização curricular, Sachs (citado por Day, 2006: 89) associa aos professores a identidade empresarial: "Esta identidade poderá caracterizar-se como sendo individualista, competitiva, controladora e reguladora, definida externamente e orientada para standards".

Deste modo, os processos de mudança e inovação curriculares acentuam o processo de retylerização da escola, cada vez mais pensada em termos de um instrumentalismo técnico, pois "a missão a ser cumprida pelo currículo não é educacional, no sentido tradicional, mas deriva do que se considera serem as necessidades da economia" (Moore \& Young, 2001: 200). Por isso, a metáfora da produção é a que se aplica de forma apropriada à escola dos dias de hoje, tão marcada pela noção de engenharia social, cujo predecessor (Thorndike) compara a educação a um complexo motor de automóvel - "se conseguíssemos pelo menos fazer o ajuste certo - no ensino, na aprendizagem, na avaliação - ele zumbiria, e nos transportaria ao nosso destino, a terra prometida de elevados resultados nos testes, ou, para muitos de nós, na esquerda educacional, a uma sociedade verdadeiramente democrática" (Pinar, 2006: 109) - no seguimento do pragmatismo, identificado com os trabalhos de James (2005 [1907]), para quem a ênfase da filosofia, e também da educação, está na utilidade prática e nos resultados.

\section{A ressignificação do currículo}

\subsection{Conhecimento, currículo e competitividade}

"Sendo o currículo o esteio do fenómeno educativo", nas palavras de Morgado \& Ferreira (2006: 77), a globalização reforça a centralidade do currículo como veículo de conhecimento, que passa a ser valorizado como um recurso económico. No documento Objectivos futuros concretos dos sistemas de educação e formação ${ }^{8}$, da União Europeia, o papel da educação e formação é tão-só o de tornar a Europa "na economia baseada no conhecimento mais dinâmica e competitiva do mundo, capaz de garantir um crescimento económico sustentável, com mais e melhores empregos, e com maior coesão social"9.

Além de outros aspectos, que reforçam a relação entre conhecimento, currículo e competitividade, os sistemas de educação e formação devem 
desenvolver competências para a sociedade do conhecimento, pelo que a riqueza das nações não depende somente de recursos naturais. Deste modo, e para que se cumpra o compromisso estratégico da Agenda de Lisboa, assumido pelos países da União Europeia, em 2001, os processos de educação e formação, aos níveis formal, não formal e informal, naquilo que mais os caracterizam em termos de conhecimento - o currículo - , tornamse numa das prioridades europeias, com ênfase para o ensino superior e para novos sistemas de formação.

Não se ignorando que as decisões supranacionais da União Europeia são decisões tomadas em contexto de globalização, pois os Estadosmembros convalidam opções mais gerais, o ensino superior torna-se, pelo menos no plano da retórica dos documentos de trabalho, na alavanca da sociedade do conhecimento. Consequentemente, ao situar-se no lado da utilidade económica, a globalização cria e alarga os mecanismos que instituem padrões curriculares uniformes e homogéneos em termos de aprendizagens, e seus níveis e ciclos de organização curricular, com conteúdos orientados para a qualificação de uma mão-de-obra flexível face às contingências de uma ordem mundial. A ideia de aprendizagens profissionalizantes ganha terreno nos ensinos superior e secundário, na vertente do que Giddens (2007) designa por "cidadania produtiva", reconhecendo que as universidades não existem apenas como coadjuvantes das empresas, ou como recurso para a economia ${ }^{10}$.

O ponto arquimédico da alavanca da sociedade do conhecimento está situado nos espaços europeus de ensino superior e de aprendizagem ao longo da vida, outorgando-se à universidade um papel crucial no triângulo conhecimento/criatividade/inovação ${ }^{11}$. No quadro da Agenda de Lisboa, a reforma das universidades baseia-se no Processo de Bolonha ${ }^{12}$, com a finalidade de fazer convergir os sistemas de ensino superior. Neste âmbito, a universidade europeia é vista como um recurso de promoção da sociedade de conhecimento, cujos ciclos de organização dos cursos de graduação e pósgraduação se encontram inteiramente uniformizados, tanto na lógica de créditos quanto na necessidade de identificar resultados da aprendizagem, conferindo sentido às palavras de Readings (2003: 13):

a universidade está a tornar-se uma empresa burocrática transnacional, quer ligada a instâncias governamentais transnacionais como a União Europeia quer 
funcionando independentemente, por analogia com uma empresa transnacional.

Trata-se de conferir sentido à crítica, que Lyotard (2006[1979]) faz à universidade, que perde a sua função de legitimação especulativa para adquirir uma função profissionalizante, precisamente porque promove um enunciado prescritivo de valor prático ligado às competências e porque se torna numa instituição funcional. A implementação do Processo de Bolonha em Portugal (Morgado, 2006) configura-se num processo técnico de mudança curricular, com relevo para a estrutura dos cursos e para a adopção de uma linguagem pedagógica centrada nos resultados, antevendo-se que a mudança nos processos de aprendizagem não sejam suficientemente significativos. Em Declaração ${ }^{13}$, Bolonha corresponde a políticas educativas com vista à mobilidade dos alunos e comparabilidade dos cursos; em Processo ${ }^{14}$, significa a existência de políticas curriculares uniformizadas no que diz respeito à formatação dos ciclos, a um sistema europeu de créditos e à formulação de resultados da aprendizagem (learning outcomes).

A nova organização curricular pressupõe a pedagogia de objectivos não como ponto de partida, mas como ponto de chegada. Assim, a formulação de resultados da aprendizagem inscreve-se numa prática tyleriana, querendo significar o que os alunos devem saber no final do processo de aprendizagem. Digamos que muitos professores universitários, em Portugal, tiveram de reler os autores da pedagogia por objectivos e buscar, artificialmente, as diferenças entre um objectivo e um resultado de aprendizagem. No entanto, objectivo e resultado são iguais se ambos exigirem três aspectos fundamentais da pedagogia comportamentalista: objecto (conteúdo), operação mental (o que se pede ao aluno e que as taxonomias definem em classes de aprendizagem) e resultado (comportamento esperado e regulado pela avaliação); são diferentes, no tempo da sua formulação, já que o objectivo orienta o processo de aprendizagem e o resultado diz respeito ao domínio de conhecimento que um aluno revela possuir no final desse processo.

Assim, os resultados de aprendizagem impõem à organização curricular do ensino superior o princípio da pedagogia por objectivos, ainda que mitigado pela pedagogia de competências, subordinado à abordagem sistémica (na busca da eficiência entre inputs e outputs). O Processo de Bolonha impõe quer um "novo conceito de aprendizagem", ainda que velho na 
tradição escolar ${ }^{15}$, apoiado em três vertentes: lectiva (tempo real dedicado pelo professor); tutorial (tempo real de diálogo entre professor e aluno); investigativa (tempo real que o aluno dedica ao estudo e pesquisa), quer uma metodologia activa (em especial, uso das tecnologias de informação e comunicação, de que as plataformas de ensino são o caso mais notório), quer ainda uma avaliação formativa (em que o exame tradicional deve ser substituído por "práticas avaliativas negociadas", isto é, consensualizadas entre professores e alunos).

O outro ponto arquimédico da economia do conhecimento é o espaço europeu de aprendizagem ao longo da vida, que é criado no âmbito da Agenda de Lisboa, com a finalidade "de incidir na aprendizagem que vai do ensino pré-escolar até à pós-reforma ("do berço ao túmulo"), abrangendo também qualquer tipo de educação (formal, informal ou não formal)", (Silva, 2007) ${ }^{16}$. De entre os múltiplos sentidos que o termo encerra (Lima, 2007; Canário, 2007a), de acordo com as alterações da economia nas sociedades capitalistas e seus impactos nos contextos de trabalho (Castro, Guimarães \& Sancho, 2007), a União Europeia tem utilizado este conceito no sentido da economia da formação, querendo significar a aquisição contínua de "conhecimentos, aptidões e habilidades", com vista a promover a mobilidade dos trabalhadores no interior da comunidade, em função da sua qualificação, de acordo com o memorandum da Comissão ${ }^{17}$.

Relacionado com as medidas de concretização do espaço europeu de aprendizagem ao longo da vida encontra-se a ressignificação do currículo, por força da valorização da educação/formação não formal e informal, que ganha um novo estatuto, deixando de ser complementar na perspectiva de uma formação entendida como reciclagem da formação inicial.

No caso de Portugal, o Programa governamental Novas Oportunidades, inserido no Plano Nacional de Emprego e no Plano Tecnológico, tem como ponto de partida o diagnóstico de que há insuficiente nível de qualificação da população, estruturando-se em dois eixos principais: qualificação de jovens e qualificação de adultos. Deste modo, a Europa, para poder competir no contexto da globalização,

tem que competir com base no valor acrescentado, com base no conhecimento e com base no capital humano. E, por isso, uma Europa baseada no conhecimento é uma Europa que tem como factores críticos de formação a 
dimensão/formação, a dimensão/qualificação, a dimensão/competência, a dimensão e capacidade de incorporar qualificação e competência nos processos produtivos (Zorrinho, 2008: 29).

Partindo de um conceito amplo de formação, a aprendizagem ao longo da vida responde às mudanças da "economia de conhecimento /serviços", no dizer de Giddens (2007: 93), em função de novas divisões sociais e dos critérios para a mobilidade dos trabalhadores, já que no contexto da sociedade pós-industrial, as credenciais (certificados, diplomas, graus) são de importância acrescida.

Com a aplicação de medidas para cumprir os objectivos estratégicos da Agenda de Lisboa, sucessivamente adiados pela falta de investimentos significativos, as oportunidades de formação ocorrem em contextos de mobilidade (programas Sócrates e Leonardo da Vinci, por exemplo) e novas modalidades de aquisição e domínio de conhecimento, em que se confrontam lógicas curriculares distintas, com tendência para a "desvalorização do processo de aprendizagem em detrimento do resultado [que] pode ser entendido como um sinal de influência da ideologia da racionalização da "performatividade" na educação, subvertendo princípios e finalidades educativas mais amplas" (Pires, 2007: 35).

Porém, e contrariamente ao que o conceito de aprendizagem ao longo da vida implica, o Programa Novas Oportunidades visa "dotar os cidadãos das competências essenciais à moderna economia do conhecimento" através de duas estratégias fundamentais: "fazer do ensino profissionalizante de nível secundário uma verdadeira e real opção"; "elevar a formação de base dos activos"18 pelo sistema de reconhecimento, validação e certificação de competências".

O primeiro pilar enunciado concretiza-se nas modalidades Formação de Jovens e Formação de Adultos, ambas organizadas numa lógica curricular muito marcada pela "validação académica" (Rothes, 2007: 81), a que correspondem cursos, por exemplo, Cursos de Educação e Formação (CEF) e Cursos Educação e Formação de Adulto (EFA), que prolongam a formação de índole institucional.

Quando o sentido deveria ser o da valorização das aprendizagens não formais e informais, o que se verifica, em Portugal, é o redimensionamento da formação escolar, colocada ao serviço da educação de adultos e, sobretudo, dos objectivos relativos à redução do insucesso e eliminação do abandono 
escolares. Também se reconhece que tais modalidades devem fazer com que os portugueses, em poucos anos, atinjam a percentagem europeia de pessoas que têm o ensino secundário, considerado o patamar mínimo da formação.

Tanto os CEF como os EFA e os Cursos Profissionais, com a tendência para que a dicotomia entre "ensino de prosseguimento de estudos" e "ensino profissional" se equilibre em termos de ofertas curriculares no ensino secundário, estão direccionados, na busca da complementaridade entre formação escolar e formação profissional, para a qualificação de jovens e adultos na reprodução do modelo escolar. Ao manter-se refém desta dicotomia, como reconhece Canário (2007b: 169), o Programa Novas Oportunidades corresponde, nestes cursos, a "um conjunto de ofertas de segunda oportunidade, destinado fundamentalmente a colmatar problemas ligados quer ao abandono precoce da escolarização, quer aos elevados números de insucesso escolar, quer à ineficácia do chamado serviço ensino recorrente". E o que a investigação educativa tem evidenciado é que "a reprodução do modelo escolar tradicional para públicos de adultos - bem como para jovens com dificuldades, e outros grupos afastados do sistema formal - não constitui um caminho adequado, na medida em que reforça os factores de exclusão, quando se torna necessário desenvolver no sistema estratégias mais inclusivas" (Pires, 2007: 36).

De índole individual, e com base nas competências ligadas à valorização das aprendizagens adquiridas pela experiência, ganha terreno a rede de Reconhecimento, Validação e Certificação de Competências, dentro de uma lógica curricular mais dependente dos "critérios valorizados pelos empregadores" (Rothes, 2007: 81) em função de competências-chave. Se o reconhecimento de adquiridos tem uma longa tradição nos sistemas de educação e formação, a sua pertinência, na primeira década do século XXI, deve-se pela imposição do modelo das competências, que se traduz, para Canário (2006), na responsabilização pessoal, na sociedade caracterizada pelo desemprego estrutural e pela precariedade dos contratos de trabalho, em dinâmicas de integração supranacional, no declínio do projecto político e social do Estado-Providência.

Numa extensão das actividades dos Centros de Reconhecimento, Validação e Certificação de Competências (CRVCC), numa primeira fase, aos 
ensinos básico e secundário e, numa fase posterior, não muito longínqua, ao ensino superior, a educação de adultos adopta um modelo curricular baseado em módulos de formação, distribuídos por áreas básicas do conhecimento (Cidadania e Empregabilidade; Tecnologias da Informação e Comunicação; Linguagem e Comunicação; Matemática para a Vida), definidas em função de competências-chave da aprendizagem ao longo da vida ${ }^{19}$. Com efeito, tratase de aplicar à educação de adultos a concepção mais aberta de currículo, longe do modelo prescritivo da educação escolar, pois o percurso de escolarização é mínimo face às necessidades de formação ditadas pela avaliação do trajecto individual, ou, noutras palavras, pela portfoliação curricular. Mesmo assim, esta modalidade de formação não se liberta totalmente do modelo escolar, estando muitos dos Centros sedeados em escolas com cursos profissionais, para além de empresas, sindicatos e associações.

Das críticas que são feitas aos CRVCC, destacamos as ideias relativas à rasura de estatísticas sobre a educação e formação e ao facilitismo. Sublinha Melo (2007: 194) que "a educação de adultos não pode restringir-se a um processo de certificação ("a um apagar de estatísticas embaraçantes"), devem considerar-se os "CRVCC apenas como um dos instrumentos de um subsistema coerentemente articulado".

Com o aproveitamento político de um sistema que pode tornar-se num grande produtor de certificados (Fragoso, 2007) nos imaginários escolar e académico, os CRVCC estão associados a facilitismo, principalmente se forem transformados em meros locais de certificação 20 , ou em locais de escolarização acelerada, sem atenderem às especificidades da educação não formal e informal, acentuando a sua pedagogização, como refere Silva (2007: 302):

Esta tendência prescritiva e normativa da aprendizagem, que pretende elevá-la à visibilidade social — por via de uma certificação que procura assegurar a competitividade no mercado e a solução de problemas que, em grande medida, Ihe transcendem -, dissocia-a do sentido e do local da sua produção/apropriação, ao mesmo tempo que procura fazer crer numa congruência entre desenvolvimento individual e social.

Por isso, Melo (2007: 197) sustenta o argumento que "aplicar o método dos CRVCC aos jovens do insucesso escolar é um erro crasso, pedagógico e político; seria como emitir moeda falsa"21. 
As estratégias de implementação do conceito de aprendizagem ao longo da vida são muito diversas e todas elas pretendem que os portugueses não só concluam o ensino secundário (aumentando, por isso, o ensino profissionalizante em substituição do ensino tecnológico), como também completem os seus percursos escolares interrompidos e possam ver as suas competências certificadas. Nas modalidades de educação de jovens e adultos sobressai mais a certificação do que a qualificação, sem que se registe uma melhoria curricular ao nível do conhecimento e das metodologias, já que muitos destes cursos funcionam nos padrões curriculares das escolas dos ensinos básico e secundário. Neste sentido, Canário (2007b: 172) afirma que

a educação e formação de adultos têm vindo a ser marcadas por uma orientação triplamente redutora: privilegia a formação de recursos humanos, assume modalidades escolarizadas e dirige-se à capacitação individual. O sucesso deste programa depende da capacidade de ultrapassar esta prática redutora.

\subsection{Currículo Nacional}

Aceitando-se como premissa que a educação responde a questões de conhecimento, perspectivado nas suas diferentes dimensões, defender-se-á também que o currículo, enquanto conteúdo de aprendizagem, estrutura e molda o sistema educativo, definindo quer a selecção e organização do conhecimento quer os itinerários de aprendizagem dos alunos em contextos de educação e formação formal, não formal e informal.

A análise dos processos e práticas de educação e formação das últimas décadas, em Portugal, conduz-nos ao reconhecimento de que o currículo tem uma presença significativa nas políticas educacionais, sobretudo pelas dimensões nacional e internacional que as reformas curriculares têm assumido no âmbito das reformas educativas.

$\mathrm{Na}$ discussão e implementação das reformas educativas portuguesas, o currículo tem adquirido uma centralidade largamente valorizada, ainda que muitas vezes criticada porque secundariza outros pontos críticos da reforma. Os dois principais momentos de reforma educativa são os de 1947 (em pleno período do Estado Novo) e 1986 (coincidente com a publicação da Lei de Bases do Sistema Educativo). Tanto num como noutro, a discussão das questões curriculares tornou-se notória ${ }^{22}$, tendo adquirido, inclusive, uma 
importância acrescida e que resultaria, nos finais do século, na reforma da "gestão flexível do currículo" (1997 e 1998).

A "curricularização" das reformas educativas traduz o lado menos positivo do currículo, observando-se que a mudança corresponde tão-só a alterações de disciplinas e cargas horárias na organização curricular, à revisão de normativos ligados à avaliação, à gestão das escolas, às faltas dos alunos e pouco mais, ficando de lado as mudanças estratégicas e inovadoras. Esta tendência para a "curricularização" das reformas educativas ganha mais relevância com os processos e práticas de educação europeia, orientados para a valorização do conhecimento e para a aquisição de competências básicas e estruturantes, num contexto de aprendizagem ao longo da vida. A ideia da europeização do currículo (Pacheco \& Vieira, 2006) é algo que passa da mera utopia para a realidade educacional, num processo gradual de convergência de políticas alicerçadas em textos fundacionais, que impõem conteúdos nos ensinos básico e secundários e ciclos de formação no ensino superior.

Por força da sua pertença à União Europeia, e por força da sua localização semi-periférica, estão a ocorrer, em Portugal, outras mudanças, entendidas como subtis, mas cujo efeito será mais efectivo do que uma reforma. É o que se passa com a diversidade de ofertas curriculares nos ensinos básico e secundário, em função do fomento do ensino profissionalizante e da certificação de competências, com vista à melhoria da qualificação dos portugueses. Por conseguinte, os processos e práticas de educação e formação estão, cada vez mais, integradas num ciclo de mandato, cujo eixo de influência se situa no quadro comum das políticas comuns da União Europeia. O novo princípio de integração supra-estatal, mais rápido na política do que na teoria, segundo Bauman (1999: 71), obedece a um cenário global em que a competição se dá "entre grupos de Estados e não entre os próprios Estados".

No contexto das políticas globalizadas, as reformas curriculares dos ensinos básico e secundário têm focalizado o reforço do currículo nacional e o controlo dos resultados de aprendizagem. Tal controlo curricular insere-se numa regulação conceitual, a montante, ao nível dos organismos transnacionais e supranacionais, e numa regulação normativa, a jusante, no plano da intervenção de cada Estado. 
Por mais uniformização que possa implicar, a globalização não significa o fim do currículo nacional, pelo contrário, eleva-o a categoria principal, sobretudo se funcionar como instrumento de formação em literacias estruturantes, dentro de um processo de autonomia que é recontextualizado em resposta a novos desafios económicos e políticos 23 .

O currículo nacional faz parte das reformas educativas com lógicas diferentes: por exemplo, em Inglaterra e nos Estados Unidos, é legitimado pelo neoconservadorismo cultural $^{24}$, caracterizado pela restauração de valores tradicionais e pela defesa de relações autoritárias nas escolas e pela ênfase no conhecimento mais conservador; em Portugal e no Brasil, é legitimado pela ideologia de mercado, visível não pelas formas de privatização da escola, mas pela instauração de uma cultura curricular de prestação de contas. Trata-se, neste último exemplo, de conferir uma pretensa autonomia às escolas, tornando-as mais competitivas e exigindo-se-lhes uma acção inscrita num projecto educativo ou num projecto político-pedagógico.

Se os resultados sobre o projecto educativo nos ensinos básico e secundário, em Portugal, são conhecidos, verificando-se a tendência para a sua ritualização (Pereira, 2006) e normatividade (Roldão, 2005), o projecto educativo é uma obrigação escolar que em nada altera as práticas pedagógicas.

Ao ligar-se à problemática do conhecimento, o currículo nacional é olhado pelo prisma das políticas de prestação de contas, como um capital informacional que obedece ao princípio, enunciado por Lyotard (2006[1979]: 81-83), da optimização das performances, isto é, a busca da melhor relação entre input/output e que permite a abertura de um vasto mercado de competências operacionais. Admite-se, assim, que o conhecimento tem um poder significativo, mas desde que seja circunscrito à resolução de problemas e ao saber prático, com expressão no domínio das competências procedimentais, entendidas em lógicas de responsabilização individual (Canário, 2005) e de empresarialização do conhecimento (Alves, Estêvão \& Morgado, 2005).

Não é sem sentido que a linguagem das competências 25 se transforme num elemento útil para a definição de um padrão curricular, necessitando a economia mundial de mercado de uma escola bem estruturada, através de saberes básicos e úteis que respondam de modo 
eficaz ao que deve ser a formação adequada dos cidadãos. De acordo com tal perspectiva, "procura-se formar mão-de-obra tecnificada, abundante e barata, e habilitar ou treinar o homo faber em detrimento do homem integral, ideado pela paidéia moderna. Semelhante às fábricas que produzem mercadorias, o sistema educativo deve produzir outra mercadoria designada capital humano (Gambôa, 2003: 85).

Para o cumprimento do currículo nacional, a regulação política impõe a terminologia de competências. Fala-se, assim, de competências metodológicas (transversais) e de competências funcionais (operacionais, comportamentais). Com efeito, no contexto da educação para a cidadania, o percurso de formação do aluno é definido pelas competências essenciais, ou seja, competências gerais da educação básica, que definem o perfil à saída do ensino básico, e competências específicas, correspondentes às situações de aprendizagem previstas para as áreas/disciplinas; no segundo caso, o brasileiro, os parâmetros curriculares nacionais, que correspondem basicamente a programas, são apresentados pelo Ministério da Educação como uma referência para a transformação dos objectivos, conteúdos e didáctica dos ensinos fundamental e médio 26 .

Uma outra realidade curricular diz respeito à transversalidade 27 , apresentada como um complemento, e não no sentido de alternativa, às áreas curriculares ditas tradicionais, com expressão escolar em temas ligados às questões sociais, incluindo as diversas educações (sexual, para a saúde, ambiental, etc.). Quer a transversalidade quer a interdisciplinaridade, quando introduzidas de forma complementar na organização curricular, podem significar o "envernizamento do conhecimento", como sugere Dalarosa (2003: 207).

Neste contexto de controlo curricular, o conhecimento é reduzido a uma perspectiva mais pragmática, com a valorização de saberes de determinadas disciplinas, a que não é indiferente o seu valor simbólico, e com o recurso a orientações tecnicistas, incutindo-se nos alunos, pais e professores a visão utilitária da escola.

Além do currículo nacional, a valorização dos resultados escolares é uma faceta fundamental das reformas curriculares, mormente pelo significado da avaliação externa (por exemplo, os exames nacionais, introduzidos em Portugal no sistema educativo no final do ensino secundário e básico em 1994 
e 2005, respectivamente), da avaliação aferida, iniciada no ensino básico em 2000, do reforço da avaliação sumativa e da ausência da avaliação formativa, ainda que esta modalidade seja contemplada, no caso português, como principal modalidade de avaliação em todo o ensino básico. Faz ainda parte desta faceta, a avaliação das escolas e dos professores, com tendência para que o professor seja "julgado" em função do insucesso escolar dos alunos, pelo que o seu salário pode começar a ser indexado aos resultados obtidos pelos seus alunos nas provas nacionais e à opinião das famílias.

A centralidade do currículo nacional e da cultura de avaliação sumativa produz dois efeitos escolares. Sobre o primeiro, o controlo é transferido dos objectivos para os resultados. A cultura de prestação de contas legitima a concepção de políticas curriculares e dos seus mecanismos de implementação nas escolas, dado que a educação é perspectivada como um valor acrescentado. Os indicadores do valor - quantitativo - da escola são mais os processos externos (exames, avaliação aferida, rankings) e comparativos (por exemplo, o estudo PISA) do que os processos internos (avaliação formativa).

Quanto ao segundo efeito, a descentralização adopta como pressupostos a autonomia das escolas e a responsabilização dos actores, tornando-os cúmplices das políticas dimanadas da Administração central. A uma maior autonomia das escolas não corresponde per se uma maior autonomia curricular, pois o currículo nacional define não só o que (planos curriculares, disciplinas, programas) e quando ensinar (número de tempos lectivos por disciplina), bem como a metodologia de ensino (orientações curriculares e metodológicas, incluindo recursos e materiais) e as regras de avaliação. A escola fica com competências essencialmente pedagógicas, sobretudo as que estão ligadas à organização das situações de aprendizagem. Trata-se de outorgar às escolas competências funcionais, dentro do conceito de escola como organização, ou escola operacional28, estando estas obrigadas a elaborar um projecto educativo, ou político pedagógico.

Ao responsabilizar os professores pelos resultados escolares, a Administração central estabelece uma relação directa com as escolas, com tendência para a celebração de contratos de autonomia, diminuindo tanto o papel dos sindicatos, quanto os poderes regionais e incentivando a 
competitividade educacional através dos recursos financeiros. Deste modo, as escolas são convidadas a apresentar propostas para a redução do insucesso escolar e os municípios são chamados a desempenhar um papel mais activo, especificamente ao nível da organização dos conselhos municipais de educação ${ }^{29}$ e da leccionação de componentes extracurriculares, nas quais se integram, digamos que erradamente, as actividades de enriquecimento curricular de vertente disciplinar.

A autonomia das escolas concretiza-se, por conseguinte, no quadro do reforço do municipalismo, com a Administração central a transferir para as Câmaras Municipais parte das suas competências curriculares, na tentativa de criar pequenas redes auto-reguladas pelos resultados, na lógica do que Brinhosa (2003: 53) designa "prefeiturização dos serviços públicos", para o Brasil, e do que poderemos designar, para Portugal, da municipalização da educação e formação.

Para além dos efeitos do currículo nacional e dos resultados, as reformas curriculares, na geografia educativa da União Europeia, traduzem-se em registos de formação centrados na aquisição de competências, ligadas às Ciências, à Matemática, ao Inglês e às Tecnologias de Informação e Comunicação, com vista à edificação da Europa do conhecimento. A língua é um factor preponderante na cimentação de uma cultura comum e o Inglês transforma-se, na União Europeia, na segunda primeira língua:

No entanto - enquanto houver vontade política para isso - nada depõe a fortiori contra a possibilidade de se criar o contexto comunicacional politicamente necessário em uma Europa que cresce unida (económica, social e administrativamente) e na qual se dispõe de uma base cultural comum e uma experiência histórica conjunta de bem-sucedida superação do nacionalismo. $\mathrm{Na}$ verdade, para que esse contexto de comunicação se estabeleça parece faltar apenas um desencadeamento por via jurídica constitucional. Também a exigência de uma língua comum - inglês como second first language poderia deixar de representar um empecilho intransponível, haja vista a situação actual da educação escolar formal nos países europeus. Identidade europeia não pode significar senão unidade na pluralidade nacional (Habermas, 2002: 184).

Nesta nova ordem curricular, o mundo da escola tem de estar ligado ao mundo do trabalho, alfa e ómega da contextualização das competências, pois só desse modo é que se torna possível falar, conjuntamente, de políticas de educação e formação - em que a educação ganha uma parceria que lhe confere razão de ser em termos de uma educação vocacional e 
profissionalizante, na lógica de uma aprendizagem ao longo da vida, de matriz qualificante, que ultrapassa a noção de educação permanente - numa ligação que justifica o conhecimento dos contextos de trabalho. Deste modo, educar será qualificar, com os sentidos que vai adquirindo à medida que o conhecimento se torna mais funcional e operacional para o aluno.

Não é por mero acaso que as recentes reformas do currículo, por vezes através da aprovação de normativos avulso, têm focalizado não só disciplinas que conferem um conhecimento pretensamente mais objectivo (e a Matemática será o conhecimento-chave de todas as mudanças tecnocráticas), mas também áreas que potencializam a formação, caso do Inglês, perspectivada como língua franca ${ }^{30}$, e das Tecnologias de Informação e Comunicação.

De modo mais concreto, o controlo curricular administrativo em Portugal acentua-se no ensino básico, mormente nos primeiros quatro anos de escolaridade. A gestão do currículo, que estava definida no cômputo geral de 25 horas semanais de leccionação, deixando-se a iniciativa aos professores para decidir sobre o tempo atribuído às quatro áreas curriculares (Matemática, Língua Portuguesa, Estudo do Meio, Expressões), é agora regulada por normativo, impondo tempos iguais para todos os alunos aprenderem os conteúdos dessas áreas. Do mesmo modo se acentuam as orientações curriculares para a educação pré-escolar e para as áreas curriculares não disciplinares (Área de Projecto; Estudo Acompanhado; Formação Cívica) e se impõem exames nacionais no fim do ensino básico ( 9 ํㅗ ano de escolaridade) a Língua Portuguesa e a Matemática. A avaliação aferida, definida politicamente como instrumento de avaliação de escolas e professores, é utilizada nos anos terminais dos ciclos do ensino básico (4ํㅜㄴㅡㅜ e $9^{\circ}$ anos de escolaridade).

Além disso, a Administração central concebe a escola como local de implementação de políticas e retoma o discurso centrado nos resultados escolares, responsabilizando os professores pelos elevados índices de insucesso e abandono que o sistema educativo ainda regista. A formação contínua de docentes está priorizada em áreas curriculares que registam taxas de maior insucesso (Matemática, Ciências, Língua Portuguesa), alimentando-se a ideia que os professores valem mais pelos seus conhecimentos da área de docência do que pelos seus conhecimentos 
pedagógicos. O conhecimento pedagógico é algo secundário nas políticas de formação contínua, mesmo que seja advogado um modelo de formação centrado nas práticas e na escola. O caso português é revelador da fragilidade de uma formação contínua, organizada em torno dos centros de associações de escolas, com ampla autonomia na elaboração dos respectivos planos de formação, mas com as áreas prioritárias a serem determinadas pela Administração central. A autonomia dos centros é essencialmente de gestão da formação, sendo os seus conteúdos e modalidades reguladas administrativamente.

Porque a homogeneização faz parte do jogo da globalização e porque a escola contém na sua organização elementos de uniformização, de que modo a educação escolar pode ser um espaço de construção de identidades em termos de projectos de formação, que incluam tanto a especificidade dos contextos escolares, quanto as esferas social e privada dos alunos?

Por mais uniformização que exista - e a escola tem nesse aspecto raízes muito profundas, pois as regras formais que a legitimam são definidas na base de princípios e modelos didácticos vinculadores de práticas recontextualizantes ${ }^{31}$ - o controlo não pode ser estabelecido numa vertente totalmente coerciva nem numa lógica de negação de uma relação pedagógica que torna impossível que o currículo seja uma "conversação complexa" (Pinar, 2007).

Apesar da existência de outras formas de organização curricular, caso da organização por projectos e da organização por competências, a escola continua a ter uma matriz conteúdal, centrada nas disciplinas, na autoridade do professor e na avaliação sumativa da aprendizagem. A visibilidade de tais formas de organização curricular nas práticas curriculares das escolas e dos professores é algo que os pesquisadores necessitam de eleger como objecto de análise na procura de mudanças significativas ou no registo de mudanças meramente administrativas.

Tais efeitos das reformas curriculares nas políticas educativas servem de fundamento ao seguinte argumento: a mudança nas escolas em termos de organização do currículo contribui mais para o reforço da autoridade curricular da Administração central do que para o reforço da autonomia curricular das escolas e da autonomia profissional dos professores. 
Tanto a escola como os professores, no quadro de regulação e assunção de competências curriculares, são secundarizados relativamente ao poder do Estado na concepção e implementação das políticas curriculares, ainda que seja reconhecido, pelo menos ao nível das regras informais existentes no interior das escolas e das salas de aula, o que faz com que as escolas construam e adoptem gramáticas de acção que em muito alteram as reformas curriculares, o poder localizante dos professores ${ }^{32}$, ainda que prevaleça uma discursividade descentralizante.

A centralidade decisional das políticas curriculares não se resume jamais às medidas específicas de cada governo, principalmente na geografia política da União Europeia, encontrando-se a sua origem em organismos transnacionais e supranacionais. Por conseguinte, a primeira regulação é conceitual e não normativa. Tais organismos "globalizados" e "globalizantes" são o rosto macropolítico de decisões curriculares, agindo como "centros de produção de significado" (Bauman, 1999), cujas faces se escondem atrás de máscaras, protegidas por conceitos económicos.

Estamos em presença de textos macropolíticos, na linguagem de Ball (1997), que ultrapassam o contexto de influência, que seria, no modelo que propõe, a primeira etapa do ciclo de produção das políticas educativas ${ }^{33}$. Compete aos Estados-membros da União Europeia, enfraquecidos nos seus horizontes de inovação educativa, assimilar a regulação conceitual e normativizar as orientações, de modo que cada sistema educativo seja uma peça de um puzzle que encaixa perfeitamente nas mudanças que se preconizam para a escola, para o currículo e para a formação de professores.

Neste sentido, a globalização não se resume a um simples programa estratégico de mudança que se situa acima dos Estados, mas a "um processo social que atravessa o Estado-nação, redefinindo-o inteiramente" (Ortiz, 2006b: 85), ou seja, o Estado-nação como arcabouço para a organização e a administração da política continua a existir como lugar de poder, ainda que parte substantiva desse poder deixe de ser articulado no seu interior em processos que conduzem à sua debilitação perante mecanismos globais (Ortiz, 2006b: 85 e 101).

Mais uma vez, os processos de reforma escolar conduzem à retylerização do currículo, instituindo-se padrões de resultados em estreita relação com o reforço do currículo nacional e com a valorização da avaliação externa e sumativa, com extensão aos processos de educação e formação 
não formal e informal, sobretudo quando são incluídos em lógicas de certificação e de escolarização.

* Este texto foi escrito na qualidade de bolsista CAPES/Brasil, na Universidade Federal de Santa Catarina e no âmbito do Projecto de Investigação "Conhecimento, Aprendizagem e Avaliação em Contextos Curriculares", do Centro de Investigação em Educação (CIEd), da Universidade do Minho.

\section{Notas}

1 Segundo Michel Mafessoli (2004: 22), o retorno ao local é uma das premissas da pós-modernidade, que recupera termos como "espaço" e "território" e remete para um sentimento reforçado de inserção, de compartilhamento emocional.

2 Na interpretação de Bernard Charlot (2007: 133), "na área da educação, o lugar mais importante para os países ricos é a OCDE. É o thinking tank, como dizem os norte-americanos, isto é o reservatório para ideias. Saíram da OCDE, a "reforma da matemática moderna", a ideia e a própria expressão de "qualidade da educação", a ideia de "economia do saber", a de "formação ao longo da vida". A OCDE é o centro do pensamento neoliberal no que tange à educação. Não é de admirar-se disso quando se sabe que foi explicitamente criada para promover a economia de mercado".

3 Para Alberto Amaral (2008: 48), "no novo método de coordenação, em vez de leis comunitárias, de âmbito europeu, passou a pedir-se a cada Estado para implementar leis de âmbito nacional para atingir os objectivos definidos a nível central, o que se torna complexo porque cada governo tem a sua agenda nacional".

4 Desenvolvemos a lógica de mercado como fundamentação das políticas educativas e curriculares no livro "Políticas curriculares. Referenciais para análise", publicado em 2003, pela Art Med.

5 "Para uma reflexão sobre os Estudos Curriculares: políticas, teorias e práticas" (III Colóquio Luso-brasileiro sobre Questões Curriculares, Braga, 2006); "Globalização e identidades educativas. Rupturas e incertezas" (Revista da Universidade Lusófona, 2006, com Nancy Pereira)."Globalização e identidade. Uma discussão escolar e curricular (Cadernos de Pesquisa, 2007, com Nancy Pereira); "Globalization, curriculum and assessment" (The Second World Curriculum Studies Conference, Finlândia, 2006, com José Carlos Morgado e Maria Palmira Alves).

6 Para Vera Candau \& Adélia Koff (2006: 487-488), na recolha de depoimentos de académicos sobre a Didáctica, permanece no imaginário docente a homogeneização como factor de facilitação do trabalho pedagógico, pois a homogeneização das turmas é cultural e secular.

7 Globalização e mundialização são descritos por Renato Ortiz a partir das categorias "economia" e "cultura", respectivamente, sendo que a mundialização é um processo externo aos países que a adoptam e a globalização é um processo interno, baseado em interesses económicos e políticos. 
8 Cf. Relatório Objectivos futuros concretos dos sistemas de educação e formação, aprovado no Conselho Europeu de Estocolmo, em 2001.

9 Cf. Relatório Objectivos futuros concretos dos sistemas de educação e formação, p.

10 Para Anthony Giddens (2007: 220), "As universidades têm de preservar a sua autonomia em relação ao Estado numa altura em que os governos querem transformá-las numa vantagem económica nacional. Uma forma de o fazer é reafirmar os valores que as universidades representam. A expansão do ensino superior não se resume a responder às exigências da nova economia. Também prepara os cidadãos para um mundo de diversidade e mudança. As disciplinas nãovocacionais continuam a ocupar a sua parte justa no currículo; e a busca desinteressada do conhecimento deve ser a função primária da universidade centrada na investigação. Os problemas enfrentados pelos EUA mostram que não é fácil resolver estas questões".

11 Cf. Aprendizagem ao longo da vida ao serviço do conhecimento, da criatividade e da inovação. Projecto de relatório do Conselho e da Comissão sobre a aplicação do programa de trabalho "Educação e Formação para 2010" [Em linha]. [Acedido em 10 de Mraço de 2008, diponível em http://eur-lex.europa.eu/ LexUriServ/ LexUriServ.do?uri=COM:2007:0703:FIN: PT:PDF].

12 Na Revista Perspectiva, volume 24, n. 1, de 2006, encontra-se um dossiê relacionado com a "Globalização e ensino superior - a discussão de Bolonha", com textos de Maria Célia Moraes, José Carlos Morgado e José Brites Ferreira. De igual modo, veja-se o texto "Políticas Educativas para o Ensino Superior na União Europeia: um olhar do lado português", publicado na Revista Educação \& Sociedade, volume 82 , № 24, de 2003, da autoria de José Augusto Pacheco. Um outro dossiê sobre o Processo de Bolonha está publicado na Revista de Educação, volume 14, no 1 , de 2006

13 Declaração conjunta dos Ministros da Educação europeus, reunidos, em Bolonha, a 19 de Junho de 1999. O documento estruturante é a Declaração de Bolonha que, para justificar o objectivo principal, enumera os argumentos da mobilidade, empregabilidade e competitividade. Só assim é que será possível construir não só um espaço de formação unificado pela inteligibilidade e comparabilidade dos graus nos sistemas europeus de ensino superior, mas também uma Europa do conhecimento, "factor indiscutível para o crescimento humano e social, sendo componente indispensável para a consolidação e para o enriquecimento da cidadania europeia, capaz de fornecer aos seus cidadãos as necessárias competências para encarar os desafios do novo milénio, bem como desenvolver a consciência de valores partilhados e relativos a um espaço comum, social e cultural". A Declaração de Bolonha é um marco preponderante na reforma do ensino superior, pautada por um conjunto de orientações determinado por um organismo supranacional e baseada tanto na Declaração da Sorbonne, de 25 de Maio de 1988, sublinhando o papel fundamental das universidades no desenvolvimento das dimensões culturais europeias, quanto na Magna Charta Universitatum, assinada por reitores de universidades europeias, em 18 de Setembro de 1988, com a finalidade de reforçar a missão da universidade, a sua independência moral e científica face aos poderes político e económico. Para que a Europa consiga adquirir um grau de atracção mundial semelhante às suas extraordinárias tradições 
cultural e científica, a Declaração de Bolonha traça seis objectivos de promoção do sistema europeu do ensino superior em todo o mundo: Adopção de um sistema de graus de acessível leitura e comparação; adopção de um sistema essencialmente baseado em dois ciclos principais, o graduado e o pós-graduado; estabelecimento de um sistema de créditos - como, por exemplo, no sistema ECTS; promoção da mobilidade, ultrapassando obstáculos ao efectivo exercício da livre mobilidade; promoção da cooperação europeia na avaliação da qualidade; promoção das necessárias dimensões europeias do ensino superior.

14 Compromisso de cada Estado-membro da União Europeia para implementar até 2010 as directrizes da Declaração de Bolonha. Em Portugal, o Processo de Bolonha é consagrado pela Lei n. 49/2005, de 30 de Agosto, que altera a Lei de Bases do Sistema Educativo, e pelo Decreto-lei n. 42/2005, de 22 de Fevereiro.

15 Poder-se-á dizer que Bolonha traz de volta um dos princípios fundamentais do ensino dos Jesuítas: relação do tempo lectivo do professor com o tempo de estudo do aluno.

16 cf. Espaço europeu de aprendizagem ao longo da vida [Em linha]. [Acedido em 4 de Abril de 2008, disponível em http://europa.eu/scadplus/ leg/pt/cha/c11054.htm].

17 Cf. http://europa.eu/scadplus/leg/fr/cha/c11047.htm [acesso 4 de Abril de 2008].

18 Cf. Novas Oportunidades. Aprender compensa. Guia de acesso ao ensino secundário - [Em linha] [Acedido em 8 de Abril de 2008, disponível em http://www.novasoportunidades.gov.pt/NovasOportunidades.aspx].

19 De acordo com o Programa Aprendizagem ao Longo da Vida, da União Europeia (cf. http://europa.eu/scadplus/leg/en/cha/c11090.htm - acedido em 16 de Abril de 2008), as competências-chave são estas: comunicação em língua materna; comunicação em línguas estrangeiras; competência matemática e competências básicas em ciência e tecnologia; competência digital; aprender a aprender; competências sociais e cívicas; sentido de iniciativa e espírito de empresa; consciência e expressão culturais.

20 Para António Fragoso (2007: 208), "Portugal não poderá contar com uma rede que sem dúvida aumentará o número actual de certificados, mas arrisca-se a deitar por terra o capital de credibilidade que o sistema possuía e a não obter para os seus cidadãos outras vantagens para além da mera certificação. Neste caso, não estamos a melhorar a situação dos adultos face à educação e à formação, mas apenas a conceder-lhes um certificado, com reflexos apenas estatísticos".

21 Alberto Melo diz mais sobre este argumento: "O RVCC não é para todos, mas só para aquela minoria de adultos que realizou de facto uma autoformação que the permita hoje aspirar a uma equivalência a graus escolares, ou imediata ou após uma curta formação complementar (por isso, se limitou a duração desta a 25 horas). Com efeito, o RVCC não foi concebido nem para jovens que abandonaram há pouco e precocemente o sistema escolar (a idade mínima de 18 anos é descabida, devendo ser prolongada para os 25 ou prova de 5 anos de experiência laboral/social contínua), nem para adultos que necessitam ainda de uma intensa aprendizagem nas competências-chave tal como se encontram descritas no respectivo Referencial".

22 Para o estudo das mudanças curriculares nos ensinos básico e secundário, veja-se Decreto-lei 286/89, de 19 de Agosto; Decreto-lei n. 6/2001, de 18 de Agosto; 
Decreto-lei n. 74/2004, de 24 de Março (alterado, em parte, pelo Decreto-lei n. 272/2007, de 26 de Julho).

23 Para Renato Ortiz (2006b: 50), "a globalização não implica o fim do Estado-Nação", produtor do currículo nacional, "o que se tem é a crise de uma instituição que já não possui a autonomia e a independência desfrutada anteriormente (...) ० Estadonação, enquanto unidade política e administrativa, se mantém, com seus dilemas e contradições no seu interior".

24 De acordo com Louise Poulson (2005: 15), "a ideologia dominante subjacente à introdução de um currículo nacional obrigatório era a do conservadorismo cultural, caracterizado pelo desejo de restaurar a tradição e práticas a ela associadas, pela defesa de relações autoritárias entre alunos e professores, pela concepção do ensino e da aprendizagem como transmissão - de um perito para um aprendiz de um corpo de conhecimentos fixo e relativamente imutável".

25 Para a discussão da pedagogia por competências como prolongamento da pedagogia por objectivos, e é essa a tese que defendemos, veja-se José Augusto Pacheco (2005b).

26 Para Adair Dalarosa (2003: 207), "pode-se afirmar que a proposta contida nos Parâmetros Curriculares Nacionais caracteriza-se num modelo tecnicista de educação, despolitizador e subjetivista, em que se toma a educação como algo descolado ou acima da realidade social, em que os problemas educacionais nem sempre são compreendidos como resultantes dos problemas da sociedade".

27 A transversalidade exigiria para a estruturação do conhecimento um código de organização relacional (cf. Pacheco, 2002) e a seguinte questão (cf. Macedo, 1999: 56): "se os temas transversais expressam as temáticas relevantes para a formação do aluno, por que não são eles os princípios estruturadores do currículo? Por que não fazer deles o núcleo central da estruturação curricular e inserir "transversalmente" as diferentes áreas do conhecimento?".

28 Adopta-se o conceito de Marilena Chauí (1999), quando fala de universidade operacional, vinculada a índices de produtividade.

29 Órgão de natureza municipal, cf. Decreto-lei n. 7/2003, que é responsável pela coordenação das políticas educativas, tendo a competência, entre outras, de analisar os resultados dos alunos.

30 Renato Ortiz (2006a) aborda o inglês como língua franca, discutindo as razões para a sua supremacia nos contextos de globalização e mundialização. No dizer de David Graddol (2006), a posição de supremacia do Inglês deve ser vista de dois lados diferentes. Do lado económico e financeiro, reconhece-se o Inglês no centro de muitos mecanismos de decisão global, surgindo, inclusive, na sua nova forma global, isto é, nos diferentes "englishs" que resultam da sua apropriação por pessoas geograficamente identificadas que lhe a usam a partir do seu modo de falar; do lado da Web, regista-se o contínuo declínio da língua de Shakespeare. Em 2005, os dados revelam esta utilização: Inglês - 32\%; Chinês - 13\%; Japonês 8\%; Espanhol - 6\%; Alemão - 6\%; Francês - 4\%; Português - 3\%. No entanto, e seguindo-se o documento elaborado para o British Council, o declínio do Inglês não se observará, dado que a sua adopção é encorajada pela classe média que habita cada vez mais nos espaços urbanos. Em percentagens estimadas, a 
economia global por Línguas, em 2010, será a seguinte: Inglês — 28,2\%; Chinês 22,8\%; Japonês - 5,6\%; Espanhol - 5,2\%; Alemão - 4,9\%; Francês - 4,2\%; Português - 3,4\% (...).

Para Anthony Giddens (2007: 257), na União Europeia, e para que haja uma esfera pública com uma forte identidade, "deve haver um acordo sobre uma língua comum que todos os cidadãos sejam incentivados a aprender. Esta língua tem de ser o inglês. O inglês já não é a língua de nações particulares. É uma língua global".

31 Por práticas recontextualizantes poderemos entender, seguindo-se o conceito de recontextualização, proposto por Basil Bernstein, modos de agir dos professores que, embora tidas como autónomas, são controladas administrativamente pelos resultados. A avaliação sumativa externa (exames nacionais) e a avaliação aferida (com a finalidade de medir a prossecução dos objectivos curriculares), bem como a elaboração de projectos curriculares de escola e de turma são alguns dos seus indicadores. A elaboração de um projecto curricular é uma prática recontextualizada quando o seu papel é o de substituir a programação da escola ou planificação dos professores, alterando-se a designação, mas não as práticas.

$32 \mathrm{Na}$ introdução ao livro de Ivor Goodson (2001), Joe Kincheloe fala do poder imperializante, para descrever formas fortes de poder, exercidas do topo para a base, e do poder localizante, para referir as formas fracas de poder, desenvolvidas a partir da base.

33 Para Stephen Ball (1997), o ciclo de produção das políticas educativas abarca, numa forma não hierárquica, as seguintes etapas: contexto de influência; contexto de produção do texto político; contexto da prática; contexto dos resultados; contexto da estratégia política.

\section{Referências}

ADICK, Christel (1993). El enfoque de sistemas mundiales en educación comparada. In J. Schriewer \& F. Pedró (eds.), Manual de Educación Comparada:Teorias, Investigaciones, Perspectivas. Barcelona: PPU, vol.2, pp. 387-421.

ALVES, M. Palmira; ESTÊVÃO, Carlos \& MORGADO, J. Carlos (2005). Desenvolver e avaliar competências na escola: metanarrativas de legitimação em confronto. In G. Figari; P. Rodrigues; P. Valois \& M. P. Alves (orgs.), Avaliação de Competências e Aprendizagens Experienciais. Saberes, Modelos e Métodos. Lisboa: Educa, pp. 255-275.

AMARAL, Alberto (2008). Comentário. In AAVV, Políticas de Educação/Formação: Estratégias e Práticas. Lisboa: Conselho Nacional de Educação, pp. 47-52.

AZEVEDO, Joaquim (2000). O Ensino Secundário na Europa. Porto: Edições Asa.

AZEVEDO, Joaquim (2007). Sistema Educativo Mundial. Ensaio Sobre a Regulação Transnacional da Educação. Vila Nova de Gaia: Fundação Manuel Leão.

BALL, Stephen (1997). Education Reform. A Critical and Post-Structural Approach. Oxford: Oxford Open University Press. 
BAUMAN, Zygmunt (1999). Globalização. As Consequências Humanas. Rio de Janeiro: Jorge Zahar Ed.

BELL, Les \& HOWARD, Stevenson (2006). Education Policy. Process, Themes and Impact. London: Routledge.

BRINHOSA, Mário (2003). A função social e pública da educação na sociedade contemporânea. In J. Lombardi (org.), Globalização, Pós-modernidade e Educação. Campinas: Ed. Autores Associados, pp. 39-60.

CANÁRIO, Rui (2005). O que é a Escola? Porto: Porto Editora.

CANÁRIO, Rui (2006). Formação e adquiridos experienciais: entre a pessoa e o indivíduo. In G. Figari; P. Rodrigues; P. Valois \& M. P. Alves (orgs.), Avaliação de Competências e Aprendizagens Experienciais. Saberes, Modelos e Métodos. Lisboa: Educa, pp. 35-46.

CANÁRIO, Rui (2007a). Aprender sem ser ensinado. A importância estratégica da educação não formal. In AAVV, A Educação em Portugal (1986-2006). Alguns contributos de investigação. Lisboa: Conselho Nacional de Educação, pp. 207267.

CANÁRIO, Rui (2007b). Multiplicar as oportunidades educativas. In AAVV, Aprendizagem ao Longo da Vida no Debate Nacional Sobre Educação. Lisboa: Conselho Nacional de Educação, pp. 167-174.

CANDAU, Vera \& KOFF, Adélia (2006). Conversas com ... sobre a Didática e a perspectiva multi/intercultural. Educação \& Sociedade, 27 (95), pp. 471-493.

CASTELLS, Manuel (2000). O Poder e a Identidade. A Era da Informação, Economia, Sociedade e Cultura. S. Paulo: Paz e Terra.

CASTRO, Rui Vieira; GUIMARÃES, Paula \& SANCHO, Amélia (2007). Mutações no campo da educação de adultos. Sobre os caminhos da formação dos educadores. Educar, 29, pp. 68-31.

CHARLOT, Bernard (2007). Educação e globalização: uma tentativa de colocar ordem no debate. Sísifo, 4, pp. 129-136.

CHAUÍ, Marilena (1999). A universidade em ruínas. In H. Trindade (org.), A Universidade em Ruínas na República dos Professores. Rio de Janeiro: Editora Vozes.

DALAROSA, Adair (2003). Globalização, neoliberalismo e a questão da transversalidade. In J. Lombardi (org.), Globalização, Pós-modernidade e Educação. Campinas: Editora Autores Associados, pp. 197-217.

DALE, Roger (2004). Globalização e educação: demonstrando a existência de "uma cultura educacional mundial comum" ou localizando uma "agenda globalmente estruturada para a educação"? Educação \& Sociedade, 25 (87), pp. 423-460.

DAY, Christopher (2006). A Paixão pelo Ensino. Porto: Porto Editora.

FERREIRA, José Brites (2006). Globalização e ensino superior: a discussão de Bolonha. Perspectiva, 24 (1), pp. 229-242.

FRAGOSO, António (2007). As Novas Oportunidades em contexto de educação de adultos: qualificação ou certificação? In AAVV, Aprendizagem ao Longo da Vida no Debate Nacional Sobre Educação. Lisboa: Conselho Nacional de Educação, pp. 201-213. 
GAMBÔA, Sílvio (2003). A globalização e os desafios da educação no limiar do novo século: um olhar desde a América Latina. In J. Lombardi (org.), Globalização, Pós-modernidade e Educação. Campinas: Editora Autores Associados, pp. 79106.

GIDDENS, Anthony (2007). A Europa na Era Global. Lisboa: Editorial Presença.

GOODSON, Ivor (2001). Curriculo em Mudança. Porto: Porto Editora.

GOUGH, Noel (2003). Globalization and school curriculum change. In S. David (ed.), Curriculum Studies. London: Routledge , IV Vol., pp. 148-162.

GRADDOL, David (2006). English Next. Why Global English May Mean the End of English as a Foreign Language. London: British Council [http:// www.britishcouncil.org/learning-research-english-next.pdf].

HABERMAS, Jurgen (2002). A Inclusão do Outro. Estudos de Teoria Política. São Paulo: Edições Loyola.

HALLAK, Jacques (2001). Politiques éducatives et contenus d'enseignement dans les pays en développement. In C. Carpentier (coord.), Contenus d'Enseignement dans un Monde en Mutation. Paris: L'Harmattan, pp. 31-52.

JAMES, William (2005 [1907]). Pragmatismo. São Paulo: Editora Nartin Claret.

JAPIASSU, Hilton (2006). O Sonho Transdisciplinar e as Razões da Filosofia. Rio de Janeiro: Editora Imago.

KOVÁCS, Ilona (2002). Qualificações e ensino/formação na era da globalização. In G. Arrigi \& S. Beverl (2001), Caos e Governabilidade no Moderno Sistema Mundial. Rio de Janeiro: Contraponto/Editora UFRJ, pp. 147-166.

LIMA, Licínio (2007). Educação ao Longo da Vida: Entre a Mão Direita e a Mão Esquerda de Miró. São Paulo: Cortez Editora.

LYOTARD, Jean-François (2006[1979]). A Condição Pós-Moderna. Rio de Janeiro: José Olympio Editora.

MACEDO, Elisabeth (1999). Parâmetros curriculares nacionais: a falácia dos seus temas transversais. In A. F. Moreira (org.), Curriculo: Políticas e Práticas. São Paulo: Papirus, pp. 43-58.

MAFFESOLI, Michel (2004). Notas sobre a Pós-Modernidade. O Lugar faz o Elo. Rio de Janeiro: Editora Atlântica.

MARTINAND, Jean-Louis (2001). Matrices disciplinaires et matrices curriculaires: le cas de l'éducation technologique en France. In C. Carpentier (ed.), Contenus d'Enseignement dans un Monde en Mutation. Paris: L'Harmattan, pp. 249-269.

MELO, Alberto (2007). Reconhecimento, validação e certificação de competências adquiridas. In AAVV, Aprendizagem ao Longo da Vida no Debate Nacional Sobre Educação. Lisboa: Conselho Nacional de Educação, pp. 193-200.

MONS, Nathalie (2004). Politiques de décentralisation en éducation: diversité internationale, légitimations théoriques et justifications empiriques. Revue Française de Pédagogie, 146, pp. 41-52.

MOORE, Rob \& YOUNG, Michael (2001). O conhecimento e o currículo na sociologia da educação: em busca de uma ressignificação. In A. F. Moreira (org.), Ênfases e Omissões no Currículo. Campinas: Papirus Editora, pp. 195-22. 
MOREIRA, António Flávio (2006). Desafios contemporâneos no campo da educação: a questão das identidades. In A. F. Moreira \& J. A. Pacheco (Orgs.), Globalização e Educação: Desafios para Políticas e Práticas. Porto: Porto Editora, pp. 11-29.

MORGADO, José Carlos \& FERREIRA, José Brites (2006). Globalização e autonomia: desafios, compromissos e incongruências. In A. F. Moreira \& J. A. Pacheco (Orgs.), Globalização e Educação. Desafios para Políticas e Práticas. Porto: Porto Editora, pp. 61-86.

MORGADO, José Carlos (2006). Globalização e (re)organização do ensino superior: perplexidades e desafios. Perspectiva, 24 (1), pp. 205-228.

ORTIZ, Renato (2006a). Mundialização e Cultura. São Paulo: Editora Brasiliense.

ORTIZ, Renato (2006b). Mundialização: Saberes e Crenças. São Paulo: Editora Brasiliense.

PACHECO, José A. (1995). O Pensamento e a Acção do Professor. Porto: Porto Editora.

PACHECO, José A. (2002). Área de Projecto: uma componente curricular não disciplinar. In A. Lopes \& E. Macedo (Orgs.), Disciplinas e Integração Curricular: História e Políticas. Rio de Janeiro: DP\&A, pp. 117-200.

PACHECO, José A. (2003). Políticas Curriculares. Referenciais para Análise. Porto Alegre: ArtMed.

PACHECO, José A. (2005a). Escritos Curriculares. São Paulo: Cortez Editora.

PACHECO, José A. (2005b). Descentralizar o discurso curricular das competências. Revista de Estudos Curriculares, 3 (1), pp. 65-91.

PACHECO, José A., Org. (2001). Políticas Educativas. O Neoliberalismo Educacional. Porto: Porto Editora.

PACHECO, José A. \& VIEIRA, Ana Paula (2006). Europeização do currículo. Para uma análise das políticas educativas e curriculares. In A. F. Moreira \& J. A. Pacheco (Orgs.), Globalização e Educação: Desafios para Políticas e Práticas. Porto: Porto Editora, pp. 87-126.

PEREIRA, Nancy (2006). Projecto Educativo. Um Estudo Sobre as Representações de Professores do 1ํ Ciclo do Ensino Básico. Dissertação de mestrado em Educação. Porto: Universidade Portucalense.

PINAR, William (2006a). The Synoptic Text Today and Other Essays. Curriculum Development After the Reconceptualization. New Work: Peter Lang.

PINAR, William (2007). O que é a Teoria Curricular? Porto: Porto Editora.

PIRES, Ana Luísa (2007). Como vamos melhorar a educação nos próximos anos, tendo em vista construir um Portugal mais moderno e mais justo? In AAVV, Aprendizagem ao Longo da Vida no Debate Nacional Sobre Educação. Lisboa: Conselho Nacional de Educação, pp. 75-83.

POULSON, Louise (2005). As políticas educativas e curriculares e o ensino do Inglês na Grã-Bretanha (1989-2004). In M. L. Dionísio \& R. V. Castro (Orgs.), O Português nas Escolas. Coimbra: Livraria Almedina, pp. 13-29.

READINGS, Bill (2003). A Universidade em Ruínas. Coimbra: Angelus Novus.

RITZER, George (2007). The Globalization of Nothing 2. London: Pine Forge Press. 
ROLDÃO, Maria do Céu (2005). Formação e Práticas de Gestão Curricular. Crenças e Equívocos. Porto: Edições Asa.

ROTHES, Luís (2007). Educação e Formação de adultos em Portugal: circunstâncias e desafios. In AAVV, Aprendizagem ao Longo da Vida no Debate Nacional Sobre Educação. Lisboa: Conselho Nacional de Educação, pp. 31-38.

SAMPAIO, Mercês (1998). Um Gosto Amargo de Escola. São Paulo: Educ.

SANFELICE, José (2003). Pós-modernidade, globalização, neoliberalismo e educação. In J. Lombardi (org.), Globalização, Pós-modernidade e Educação. Campinas: Editora Autores Associados, pp. 3-12.

SILVA, Ana Maria (2007). (In)visibilidade da formação e da aprendizagem: saberes, experiências e autorias. In J. A. Pacheco; J. C. Morgado \& A. F. Moreira (orgs.), Globalização e (Des)lgualdades: Desafios Contemporâneos. Porto: Porto Editora, pp. 301-311.

STROMQUIST, Nelly (2006). Uma cartografia del género en educación. Educação \& Sociedade, 27 (95), pp. 361-383.

TEODORO, António (2003). Globalização e Educação. Porto: Edições Afrontamento.

ZORRINHO, Carlos (2008). Políticas de educação/formação - construção do espaço educativo europeu. In AAVV, Políticas de Educação/Formação: Estratégias e Práticas. Lisboa: Conselho Nacional de Educação, pp. 29-43. 
EDUCATION AND TRAINING PROCESSES AND PRACTICES. TOWARDS AN ANALYSIS OF PORTUGUESE REALITY IN GLOBALIZATION CONTEXTS

\begin{abstract}
In a critical analysis of the recent education processes and practices, defined by the European Union's agenda and that of other organisms, we have placed at the centre of the debate the relation between globalization, knowledge and curriculum, so as to highlight the changes on the level of the formal, non formal and informal education to the curriculum study. We underline the fact that the education and training policies are complex processes of decision, dependent on different and intertwined territorialities with the objective of affirmatively respond to a broader economic-social change. It is based on this structured logic of political decision that we situate the curriculum's study in the context of globalized policies, on the one hand, and national policy, on the other hand, recognising the fact that both are edified around knowledge.
\end{abstract}

Keywords

Globalization; Education; Training; Curriculum

\title{
PROCESSUS ET PRATIQUES D'ÉDUCATION ET FORMATION. POUR UNE ANALYSE DE LA RÉALITÉ PORTUGAISE DANS UN CONTEXTE DE GLOBALISATION
}

Résumé

Dans une analyse critique des récents processus et pratiques d'éducation et formation, definis par l'agenda de l'Union européenne et d'autres organismes, nous plaçons au centre du débat la relation entre globalisation, connaissance et curriculum, de façon à mettre en évidence les changements au niveau de l' éducation formelle, non formelle et informelle pour l'étude du curriculum. Nous 
insistons sur le fait que les politiques d'éducation et formation sont des processus complexes de décision, dépendants de différentes et interliées territorialités, dont l'objectif est de répondre affirmativement à une transformation économique et social plus large. C'est dans cette logique structurée de décision politique que nous situons l'étude du curriculum dans le contexte de politiques globalisées, d'une part, et de politiques nationales, d'autre part, en reconnaissant que les deux sont édifiées autor de la connaissance.

Mots-clé

Globalisation; Éduaction; Formation; Curriculum

Recebido em Junho/2008

Aceite para publicação em Fevereiro/2009

Toda a correspondência relativa a este artigo deve ser enviada para: José Augusto Pacheco, Instituto de Educação e Psicologia, Universidade do Minho, Campus de Gualtar, 4710-057 Braga,

Portugal. E-mail: jpacheco@iep.uminho.pt 